\title{
ANALISIS KESULITAN SISWA SMP NEGERI 3 PLERET PADA MATERI ARITMATIKA SOSIAL
}

\author{
Maratu Shalikhah \\ Pendidikan Matematika, Universitas Cokroaminoto Yogyakarta \\ Jl. Perintis Kemerdekaan, Gambiran, Umbulharjo, Kota Yogyakarta 55161 \\ Email: maratushalikhah13@gmail.com
}

\begin{abstract}
ABSTRAK
Materi aritmatika sosial menjadi fokus dalam penelitian ini. Peneliti ingin mengetahui lebih dalam mengenai pemahaman siswa terkait materi aritmatika sosial. Selain itu, materi aritmatika sosial menuntut berbagai materi prasyarat yang harus dikuasai siswa. Masalah pokok yang diteliti dalam penelitian ini adalah kesalahan siswa dalam menyelesaikan soal materi aritmatika sosial. Penelitian ini bertujuan untuk mengetahui bentuk-bentuk kesalahan yang dilakukan siswa dalam menyelesaikan soal-soal yang berkaitan dengan aritmatika sosial, faktorfaktor penyebabnya, dan memberikan pemecahan pada kesalahan yang telah diidentifikasi. Subyek dalam penelitian ini adalah siswa kelas VIIIC SMP Negeri 3 Pleret. Data kesalahan siswa diperoleh dari hasil tes tertulis. Jawaban siswa yang salah diidentifikasi ke dalam jenis dan bentuk kesalahan. Setelah itu dipilih beberapa siswa untuk diwawancarai. Penelitian ini menggunakan pendekatan kualitatif dan jenis penelitiannya adalah deskriptif.

Dari hasil analisis data dapat disimpulkan bahwa siswa mengalami: (1) kesulitan dalam melakukan algoritma penyelesaian soal; (2) kesulitan dalam memahami konsep untung atau rugi jika dikaitkan dengan harga beli dan harga jual; (3) kesulitan dalam memahami konsep diskon. Alternatif pemecahan masalah mengatasi kesulitan tersebut adalah: (1) Guru perlu membiasakan dan menekankan kepada siswa agar dalam mengerjakan soal selalu disertai dengan langkahlangkah yang jelas.; (2) Menerapkan metode Role Playing (bermain peran) dengan memanfaatkan kantin sekolah.
\end{abstract}

Kata kunci: analisis, kesulitan, kesalahan, aritmatika sosial

\begin{abstract}
Social arithmetic material is the focus of this research. Researchers want to find out more about student understanding related to social arithmetic material. In addition, social arithmetic materials require various prerequisite materials that must be mastered by students. The main problem examined in this study is the student's mistake in solving social arithmetic material. This study aims to determine the forms of errors made by students in solving problems related to social arithmetic, the causes, and provide solutions to the errors that have been identified. The subjects in this study were eighth grade students of SMP Negeri 3 Pleret. Student error data obtained from written test results. Student answers are incorrectly identified into the types and forms of errors. After that, several students were selected to be interviewed. This research uses a qualitative approach and the type of research is descriptive.

From the results of data analysis it can be concluded that students experience: (1) difficulty in performing the problem solving algorithm; (2) difficulties in understanding the concept of profit
\end{abstract}


or loss if it is associated with the purchase price and selling price; (3) difficulties in understanding the concept of discount. Alternative solutions to overcoming these difficulties are: (1) Teachers need to get used to and emphasize to students so that in working on problems always accompanied by clear steps; (2) Apply themethod Role Playing by utilizing the school canteen.

Keywords: analysis, difficulty, error, social arithmetic

\section{PENDAHULUAN}

Matematika sebagai salah satu ilmu dasar mempunyai peranan penting dalam perkembangan ilmu dan teknologi. Hal ini sesuai dengan peranan matematika sebagai pembentuk nalar siswa. Dengan mempelajari matematika, diharapkan siswa dapat bernalar dan berpikir secara logis, analitis, kritis, dan kreatif. Selain itu, dengan mempelajari matematika diharapkan siswa dapat memecahkan masalah yang dihadapi baik yang berkaitan dengan matematika, maupun yang berkaitan dengan kehidupan sehari-hari. Dalam Standar Isi Kurikulum Satuan Tingkat Pendidikan (Depdiknas, 2006: 388) dijelaskan bahwa pembelajaran matematika bertujuan agar peserta didik memiliki kemampuan: (1) memahami konsep matematika, menjelaskan keterkaitan antar konsep, dan mengaplikasikan konsep atau algoritma secara luwes, akurat, efisien, dan tepat dalam pemecahan masalah; (2) menggunakan penalaran pada pola dan sifat, melakukan manipulasi matematika dalam membuat generalisasi, menyusun bukti atau menjelaskan gagasan dan pernyataan matematika; (3) memecahkan masalah yang meliputi kemampuan memahami masalah, merancang model matematika, menyelesaikan model dan menafsirkan solusi yang diperoleh; (4) mengkomunikasikan gagasan dengan simbol, tabel, diagram, atau media lain untuk memperjelas keadaan atau masalah; (5) memiliki sikap menghargai kegunaan matematika dalam kehidupan, yaitu memiliki rasa ingin tahu, perhatian dan minat dalam mempelajari matematika, serta sikap ulet dan percaya diri dalam pemecahan masalah; (6) Menalar secara logis dan kritis serta mengembangkan aktivitas kreatif dalam memecahkan masalah dan mengkomunikasikan ide.

Berdasarkan tujuan pembelajaran matematika di atas, dapat direfleksikan dengan realita pembelajaran matematika di sekolah bahwa pembelajaran matematika selama ini belumlah mampu mencapai tujuan pembelajaran tersebut. Banyak siswa yang masih kesulitan sehingga sering melakukan kesalahan dalam mengerjakan soal matematika. Sering dijumpai siswa yang hanya menghafalkan rumus-rumus tertentu tanpa memahami konsepnya. Padahal konsep dasar haruslah dipahami oleh siswa sehingga siswa tidak akan mengalami kesulitan jika dihadapkan 
pada suatu soal yang lebih rumit pada materi tertentu. Hal ini mungkin karena model pembelajaran yang digunakan kurang dapat membawa siswa untuk belajar, kegiatan pembelajaran berpusat pada guru, siswa tidak dilibatkan langsung dalam memperoleh konsep, dan cenderung sukar dalam membayangkan konkretnya. Kesulitan yang dialami siswa akan memungkinkan terjadinya kesalahan sewaktu menjawab soal tes. Pembelajaran yang selama ini mendominasi pada umumnya guru berperan sebagai sumber belajar utama. Guru menyajikan pengetahuan matematika kepada siswa, siswa memperhatikan penjelasan dan contoh yang diberikan oleh guru, kemudian siswa menyelesaikan soal-soal sejenis yang diberikan guru. Pembelajaran semacam ini kurang memperhatikan aktivitas siswa, interaksi siswa, dan pengkonstruksian pengetahuan oleh siswa. Aktivitas siswa yang dimaksudkan di sini tidak hanya sekedar menyelesaikan soal-soal sesuai contoh yang diberikan guru, tetapi perlu pula melibatkan berbagai aktivitas yang dapat merangsang kemampuan berpikir dan kemampuan memecahkan masalah yang merupakan tujuan pembelajaran matematika. Salah satu pokok bahasan dalam pelajaran matematika di Sekolah Menengah Pertama (SMP) adalah aritmatika sosial. Aritmatika sosial merupakan bagian dari matematika yang membahas tentang perhitungan keuangan dalam perdagangan dan kehidupan sehari-hari beserta aspek-aspeknya. Materi aritmetika sosial lebih menekankan pada kemampuan siswa dalam memahami konsep matematika kontekstual yang menggambarkan kehidupan sehari-hari. Namun demikian kenyataan di lapangan menunjukkan bahwa tidak sedikit siswa SMP yang kurang memiliki pemahaman konsep pada materi tersebut. Hal ini dapat dilihat dari hasil Ujian Nasional tahun 2012/2013 bahwa presentase penguasaan materi aritmatika sosial SMP di kabupaten Bantul adalah 56,66. Presentase tersebut lebih rendah jika dibandingkan dengan pressentase penguasaan materi tersebut secara nasional yaitu 60,27. Mungkin siswa SMP di kabupaten bantul mengalami kesulitan sehingga terjadi kesalahan dalam penyelesaian soal materi tersebut. Dari uraian diatas, dipandang perlu diadakan penelitian lebih lanjut tentang kesulitan siswa pada materi aritmatika sosial. Dengan penelitian ini, peneliti berharap agar bisa mengidentifikasi kesalahan siswa dan bisa menemukan alternatif pemecahan pada kesalahan yang telah diidentifikasi.

\section{METODE PENELITIAN}

Penelitian ini tergolong dalam penelitian deskriptif kualitatif yang bertujuan untuk mendeskripsikan kesalahan dan penyebab kesulitansiswa pada materi aritmatika sosial. Data 
penelitian ini berupa jawaban tertulis dan lisan yang diperoleh dari tes tertulis dan wawancara. Subjek dalam penelitian ini adalah siswa kelas VIII SMP N 3 Pleret yang terdiri atas 29 siswa. Dipilih kelas VIII karena mereka sudah mempelajari materi aritmatika sosial ketika kelas VII semester 2. Sehingga diharapkan mereka telah cukup memahami materi tersebut. Dari subjek tersebut diambil 2 siswa yang dianggap mewakili sebagai sampel yang akan dipaparkan hasilnya. Instrumen tes tertulis berupa tiga butir soal aritmatika sosial.

\section{HASIL PENELITIAN}

\section{Jawaban Tertulis dan Analisisnya}

Pada jawaban dan analisisnya digunakan simbol $\mathrm{K}_{1} \mathrm{~S}_{1}$ artinya kesalahan 1 subjek pertama, $\mathrm{K}_{1} \mathrm{~S}_{2}$ artinya kesalahan 1 subjek kedua. Begitu seterusnya.

\section{a. Subjek Pertama (Siti Mahmudah)}

Gambar 1 berikut merupakan jawaban instrumen tes tertulis dari subjek pertama.

\section{Gambar 1. Jawaban tes tertulis subjek 1}

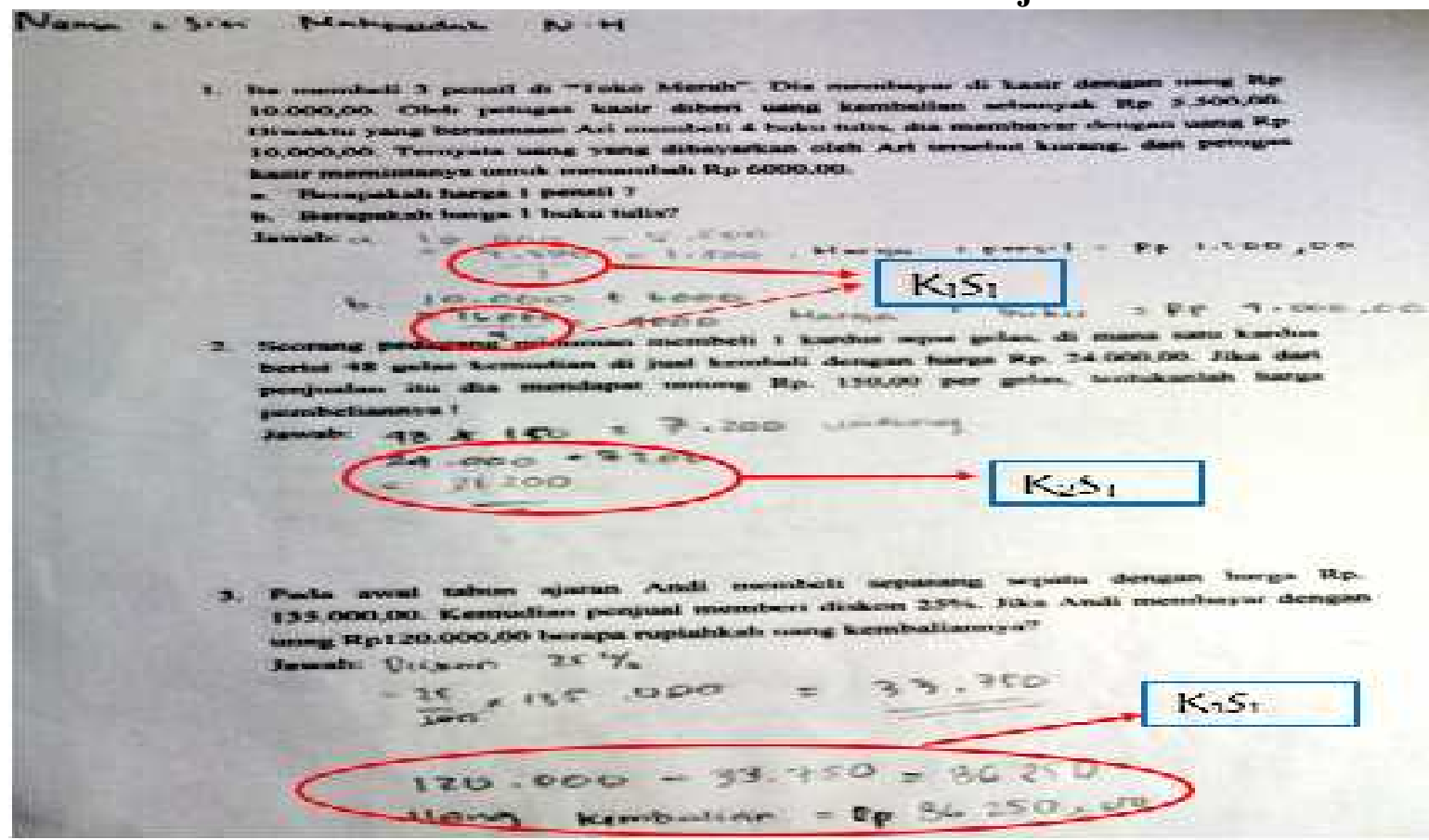

\section{Analisis:}

1) $\mathrm{K}_{1} \mathrm{~S}_{1}$ : Subjek pertama menjawab benar untuk soal nomor 1. Namun, langkah-langkahnya kurang terstruktur dengan baik. Hal itu terlihat pada jawaban tersebut bahwa setelah langkah pengurangan, tiba-tiba subjek 1 langsung membaginya dengan 3. Hal ini kemungkinan subjek 1 mengalami kesulitan dalam melakukan algoritma penyelesaian soal. Akibatnya, subjek 1 menuliskan langkah-langkah penyelesaiannya dengan kurang begitu jelas.

2) $\mathrm{K}_{2} \mathrm{~S}_{1}$ : Subjek mengetahui bahwa keuntungan total yang didapatkan penjual tersebut dapat dicari dengan mengalikan keuntungan per gelas dengan banyaknya gelas per kardus. Akan 
tetapi setelah langkah tersebut, subjek 1 tidak jelas dalam menuliskan langkah pengerjaannya. Subjek 1 mencari harga beli dengan menjumlahkan keuntungan yang diperoleh dengan harga jual. Hal ini kemungkinan subjek 1 tersebut memahami harga beli sebagai harga yang harus dibayar oleh pembeli pada penjual yang memperoleh keuntungan tersebut. Akibatnya akan terjadi kesalahan konsep antara harga jual dan harga beli.

3) $\mathrm{K}_{3} \mathrm{~S}_{1}$ : Subjek 1 telah mengetahui bahwa diskon dihitung dari harga penjualan. Akan tetapi subjek 1 menghitung uang kembalian dengan mengurangkan uang yang dibayarkan dengan besar diskon yang diberikan. Padahal uang yang dibayarkan tidak sama dengan harga penjualan sebelum diberi diskon. Hal ini kemungkinan subjek 1 memahami uang yang dibayarkan sama dengan harga jual. Akibatnya akan terjadi kesalahan konsep bahwa diskon dikurangkan dari besar uang yang dibayarkan.

\section{b. Subjek Kedua (M. Muhsin Noor)}

\section{Gambar 2. Jawaban tes tertulis subjek 2}

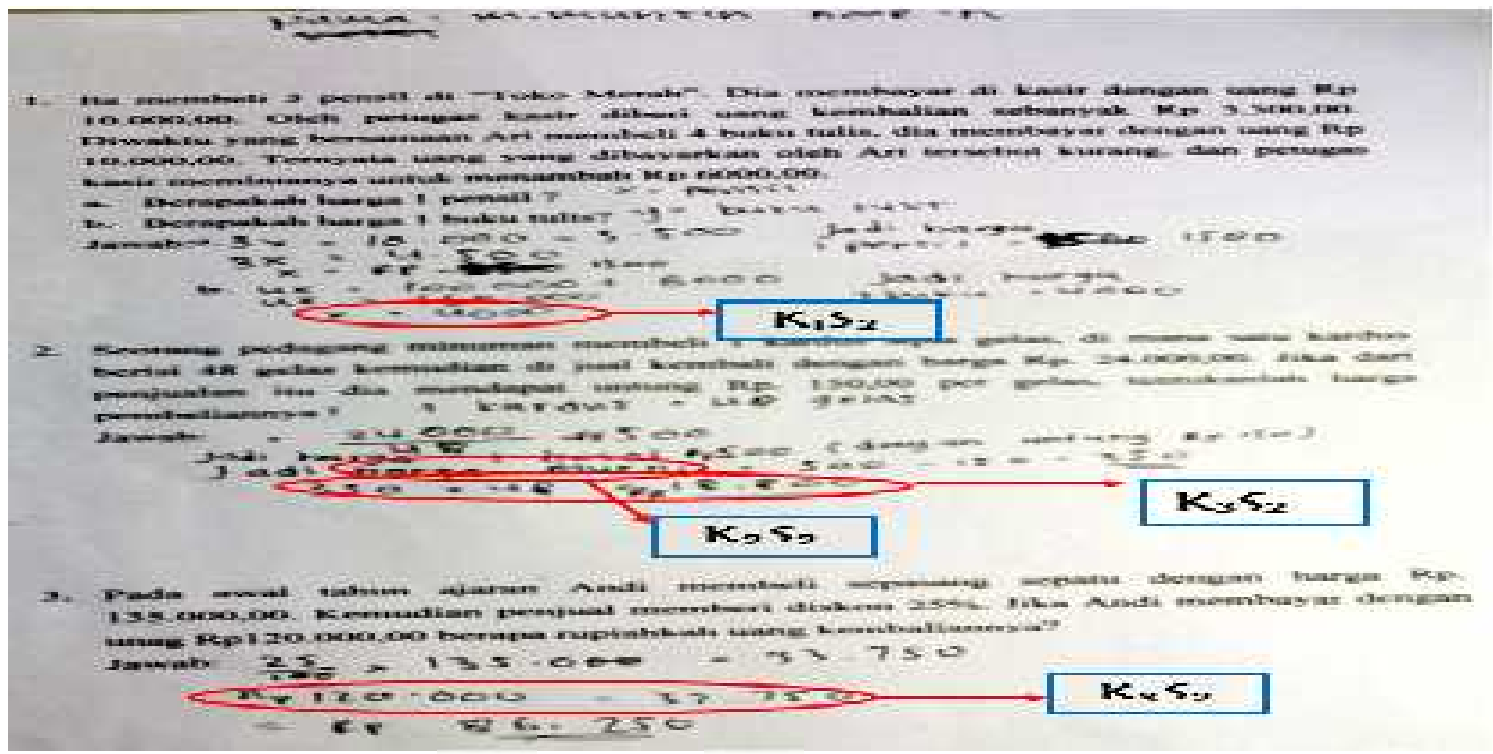

\section{Analisis:}

1) $\mathrm{K}_{1} \mathrm{~S}_{2}$ : Subjek 2 telah mampu membuat pemisalan untuk mempermudah penyelesaian soal. Subjek 2 memisalkan $x=$ pensil dan $y=$ buku tulis. Langkah-langkah penyelesaiannya juga cukup jelas. Namun dalam proses perhitungannya untuk mencari harga buku tulis subjek 2 menggunakan pemisalan $x$. Padahal sebelumnya subjek 2 telah memisalkan $y=$ buku tulis. Hal ini kemungkinan subjek 2 tidak cermat dalam mengerjakan soal tersebut. Akibatnya, subjek 2 tidak konsisten dalam menggunakan pemisalan yang telah ditentukan sebelumnya.

2) $\mathrm{K}_{2} \mathrm{~S}_{2}$ : subjek 2 menggunakan istilah harga murni. Harga murni diperoleh dari harga jual dikurangi keuntungan seperti yang tertera dalam jawaban subjek di atas. Hal ini kemungkinan subjek 2 belum memahami apa itu harga beli. Akibatnya, subjek 2 menggunakan istilah harga murni untuk menyebutkan harga beli.

3) $\mathrm{K}_{3} \mathrm{~S}_{2}$ : subjek 2 tidak memberikan keterangan dalam proses perhitungan $350 \times 48=$ 18.800. Akibatnya, jawaban dari subjek 2 menjadi kurang begitu jelas. Hal ini mungkin 
subjek 2 mengalami kesulitan dalam melakukan algoritma penyelesaian soal yang ada dalam materi aritmatika sosial, seperti harga jual, harga beli, diskon, untung, rugi, dan sebagainya. Selain itu, subjek 2 salah dalam menghitung perkalian tersebut. Hal ini kemungkinan subjek 2 tidak cermat dalam menghitung, akibatnya terjadi kesalahan dalam menghitung.

4) $\mathrm{K}_{3} \mathrm{~S}_{4}$ : Subjek 2 telah mengetahui bahwa diskon dihitung dari harga penjualan. Akan tetapi subjek 2 menghitung uang kembalian dengan mengurangkan uang yang dibayarkan dengan besar diskon yang diberikan. Padahal uang yang dibayarkan tidak sama dengan harga penjualan sebelum diberi diskon. Hal ini kemungkinan subjek 2 memahami uang yang dibayarkan sama dengan harga jual. Selain itu dimungkinkan subjek 2 juga belum memahami konsep diskon. Akibatnya akan terjadi kesalahan konsep bahwa diskon dikurangkan dari besar uang yang dibayarkan. Kesalahan yang terjadi pada soal nomor 3 ini sama dengan kesalahan yang dilakukan oleh subjek 1 .

\section{Hasil Wawancara dan Analisisnya}

Wawancara langsung dengan masing-masing subjek dengan tujuan agar bisa mengetahui alasan yang pasti dari subjek. Wawancara dilakukan dengan mengajukan beberapa pertanyaan yang dimaksudkan untuk menggali, mendengarkan dan mengetahui keterangan dari subjek. Sehingga kesulitan yang dialami subjek yang menyebabkan kesalahan dalam mengerjakan soalsoal di atas dapat diperjelas. Dalam wawancara ini ada beberapa simbol yaitu $P$ (peneliti) dan $S$ (subjek). Berikut hasil wawancara dengan kedua subjek.

\section{a. Subjek Pertama (Siti Mahmudah)}

$P$ : Dek mengapa itu untuk jawaban nomor $1 \mathrm{a}$ dan $1 \mathrm{~b}$ dalam perhitungan bisa langsung muncul $\frac{4000}{3} \operatorname{dan} \frac{16000}{4}$ ?

S: kan pensilnya ada 3 dan bukunya ada 4, jadi itu hasilnya dibagi 4 .

P: Apakah $10.000-5.500$ itu samadengan $\frac{4500}{3}$, mengapa di situ tertulis $10.000-5.500=$ $\frac{4500}{3}$ ?

S: Tidak mbak, $10.000-5.500=4.500$. Itu tertulis begitu karena itu tadi kan pensilnya ada 3 , saya bingung mau menuliskannya mbak.

$P$ : Seorang penjual dikatakan untung itu ketika bagaimana dek?

$S$ : ketika mendapatkan uang yang lebih mbak dari hasil penjualannya.

$P$ : lalu bagaimana cara menghitung besar keuntungannya?

$S$ : uang yang didapat dikurangi dengan harga aslinya mbak..

$P$ : Harga asli? Apa itu harga asli?

S: harga sebenarnya

$P$ : untuk soal nomor 2 itu tertulis Rp24.000,00 $+\mathrm{Rp} 7.200,00=\mathrm{Rp} 31.200,00$. Itu apa ya kok tidak ada penjelasannya?

$S:$ itu maksud saya harga belinya mbak.

$P$ : kenapa tidak ditulis penjelasannya dek?

$S$ : bingung mbak, ribet juga, bisanya langsung begitu juga tidak apa-apa kok mbak.

$P$ : untuk soal yang nomor 2 itu kenapa adek menghitung harga pembeliannya seperti itu?

$S$ : begini mbak, kan untung Rp7.200,00, kalo untung berarti uangnya bertambah jadi $R p 24.000,00+R p 7.200,00=R p 31.200,00$ 
$P$ : harga pembelian dan harga penjualan itu apa dek?

$S$ : harga pembelian itu harga beli barang itu mbak, kalo harga penjualan ya harga dijualnya barang itu mbak.

$P$ : Nah, kalau untung berarti harga belinya lebih besar atau lebih kecil dari harga jualnya?

$S:$ harga belinya lebih besar dari harga jualnya mbak.

$P$ : kalau rugi bagaimana?

S: harga belinya lebih kecil dari harga jualnya mbak.

$P$ : dari mana bisa tahu seperti itu?

$S$ : dari buku pelajaran mbak.

$P$ : Diskon itu apa dek?

S: Diskon itu gratisan mbak, maksudnya dimurahi gitu mbak,

$P$ : Pada soal nomor 3 itu setelah mendapat diskon berarti harga sepatunya menjadi berapa dek?

S: harganya menjadi Rp86.250,00 mbak. Eh salah itu saya nomor 3, yang ditanyakan uang kembalian ya mbak? Berarti uong kembaliannya ya Rp33.750,00.

$P$ : Waktu pembelajaran materi aritmatika proses KBM nya bagaimana?

S: seperti biasa mbak, dijelaskan terus nanti mengerjakan soal-soal.

$P$ : praktik jual beli beneran nggak dek?

S: enggak mbak.

\section{Analisis:}

1) Subjek pertama kurang dapat melakukan algoritma

2) Subjek pertama kurang memahami apa itu harga beli. Subjek pertama menyebut harga beli dengan harga asli.

3) Subjek pertama hanya mengetahui bahwa jika untung maka uangnya bertambah.

4) Subjek pertama masih belum memahami betul apa yang dimaksud dengan harga beli dan harga jual.

5) Subjek pertama mengalami kesulitan dalam memahami konsep untung jika dikaitkan dengan harga jual dan harga beli.

6) Subjek pertama memahami diskon sama dengan uang kembalian (uang yang dikembalikan)

\section{b. Subjek Kedua (M. Muhsin Noor R)}

$P$ : untuk yang nomor 1 itu kenapa buku tulis dimisalkan $x$ pada saat perhitungannya, padahal di atas kamu sudah memisalkannya $y$ ?

$S$ : oh iya mbak, saya lupa.

$P$; pada jawaban nomor 2 itu adek menuliskan harga murni, harga murni itu apa dek?

$S$ : harga murni itu harga sebelum mendapatkan keuntungan.

$P$ : lalu harga beli itu apa?

$S$ : harga beli ya harga murni tadi itu mbak.

$P$ : diskon itu apa dek?

$S$ : diskon itu potongan harga mbak.

$P$ : diskon itu dihitungnya dari harga apa dek? 
$S:$ dari harga awalnya mbak.

$P$ : nomor 3 itu harga sepatu setelah mendapat diskon $25 \%$ menjadi berapa dek?

$S:$ menjadi Rp86.250,00.

$P$ : lalu uang kembaliannya berapa?

$S$ : oiya mbak itu kurang, saya lupa mbak. Uang kembaliannya Rp120.000,00- Rp86.250,00

$P$ : Pada saat mempelajari materi aritmatika proses KBM nya bagaimana dek?

$S$ : dijelaskan terus diskusi mbak.

$P$ : diskusi bagaimana? Pakai simulasi jual beli beneran nggak?

$S$ : diskusi kelompok mengerjakan soal. Nggak pakai jual beli beneran kok mbak.

\section{Analisis:}

1) Subjek kedua kurang teliti dalam melakukan operasi aljabar.

2) Subjek kedua kurang memahami apa itu harga beli. Subjek kedua menyebut harga beli dengan harga murni.

3) Subjek kedua menyebut harga sebelum didiskon dengan sebutan harga awal.

4) Subjek kedua mengurangkan besar diskonnya pada uang yang dibayarkan.

\section{Pembahasan Hasil Penelitian}

1. Kesulitan dalam melakukan algoritma penyelesaian soal.

- Siswa menjawab dengan langkah-langkah yang kurang terstruktur dan kurang jelas maksudnya memberikan gambaran bahwa siswa mengalami kesulitan dalam melakukan algoritma penyelesaian soal. Dari hasil wawancara terlihat bahwa penyebab kesulitan siswa dalam melakukan algoritma penyelesaian soal karena siswa tidak terbiasa melakukan algoritma penyelesaian soal secara runtut.

- Ketidakkonsistenan siswa dalam menggunakan menggunakan simbol aljabar memberikan gambaran bahwa siswa tidak cermat dalam mengerjakan soal. Dari hasil wawancara terlihat bahwa penyebab ketidakkonsistenan siswa dalam menggunakan menggunakan simbol aljabar adalah karena siswa tidak cermat dalam mengerjakan soal.

2. Kesulitan mengkomunikasikan konsep-konsep yang ada dalam materi aritmatika sosial, seperti harga jual, harga beli, diskon, untung, rugi.

3. Kesulitan dalam memahami konsep untung atau rugi jika dikaitkan dengan harga beli dan harga jual.

- Kesulitan memahami konsep karena sudah terjadi miskonsepsi pada dirinya. Siswa memahami bahwa keuntungan terjadi ketika harga belinya lebih besar dari harga jualnya. Sedangkan akan terjadi rugi jika harga belinya lebih kecil dari harga jualnya. Dari hasil wawancara terlihat bahwa penyebab terjadinya miskonsepsi ini adalah karena siswa cenderung menghafalkan konsep dari buku, sehingga ketika hanya mengandalkan hafalan ini maka akan cenderung lupa dan terjadi miskonsepsi.

4. Kesulitan dalam memahami konsep diskon.

- Menghitung uang kembalian dengan mengurangkan uang yang dibayarkan dengan besar diskon yang diberikan memberikan gambaran bahwa siswa mengalami kesulitan dalam memahami konsep diskon. Dari hasil wawancara terlihat bahwa penyebab kesulitan 
dalam memahami konsep diskon terjadi karena telah terjadi miskonsepsi dalam diri siswa.

\section{A. Alternatif Pemecahan}

Berdasarkan analisis masalah di atas yaitu tentang kesalahan subjek dalam materi aritmatika sosial maka alternatif pemecahan yang peneliti tawarkan adalah sebagai berikut:

1. Alternatif pemecahan untuk mengatasi kesulitan dalam melakukan algoritma penyelesaian soal.

Dari pembahasan dijelaskan bahwa penyebab kesulitan dalam melakukan algoritma penyelesaian soal adalah karena siswa tidak terbiasa melakukan algoritma penyelesaian soal. Oleh karena itu guru perlu membiasakan dan menekankan kepada siswa agar dalam mengerjakan soal selalu disertai dengan langkah-langkah yang jelas. Hal ini sangatlah perlu dibiasakan kepada siswa agar siswa dapat menjawab soal secara terstruktur sehingga siswa akan lebih mudah dalam memahami algoritma penyelesaian soal.

2. Alternatif pemecahan untuk mengatasi kesulitan dalam memahami konsep untung atau rugi jika dikaitkan dengan harga beli dan harga jual dan kesulitan dalam memahami konsep diskon.

Kesulitan ini dapat di atasi dengan melaksanakan pemebelajaran dengan menerapkan metode Role Playing (bermain peran). Pada saat pembelajaran matematika guru dapat mengajak siswa untuk mempraktikkan secara langsung kegiatan jual beli di kelas. Dengan praktik secara langsung diharapkan siswa mampu lebih memahami konsep-konsep dalam aritmatika karena siswa mengkonstruk pengetahuannya sendiri dengan pengalaman secara langsung oleh dirinya sendiri. Pada saat praktik tersebut guru dapat mempersiapkan bahanbahan sederhana yang diperlukan misalnya adalah uang mainan, label peran, properti adegan, dan kartu adegan siswa seperti pada gambar berikut.

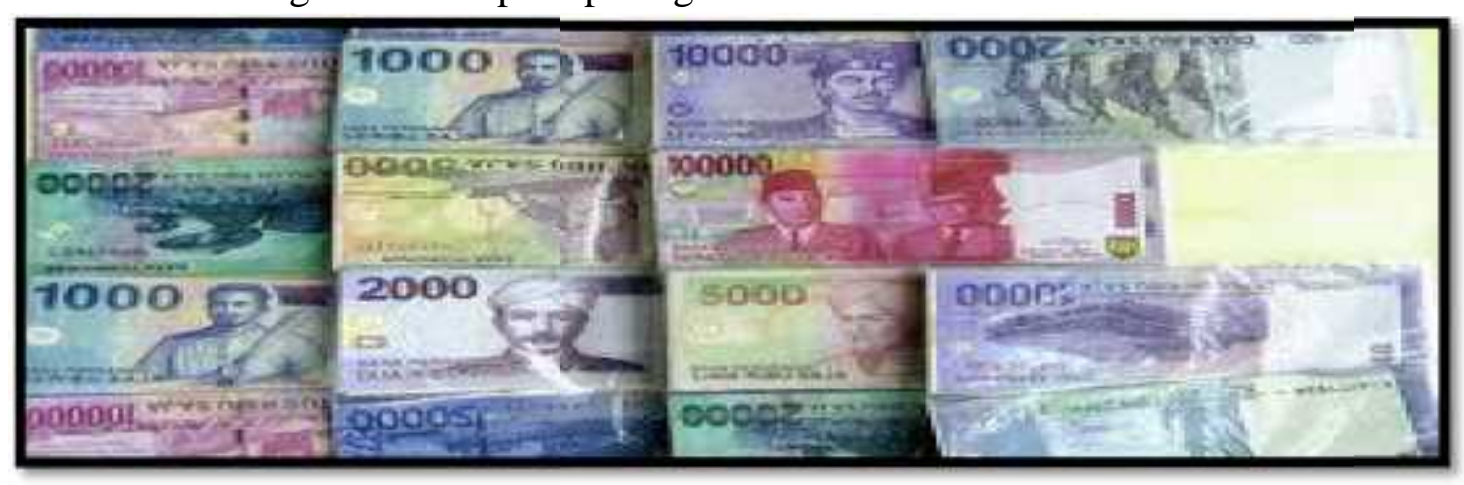

Gambar 3. Uang mainan 


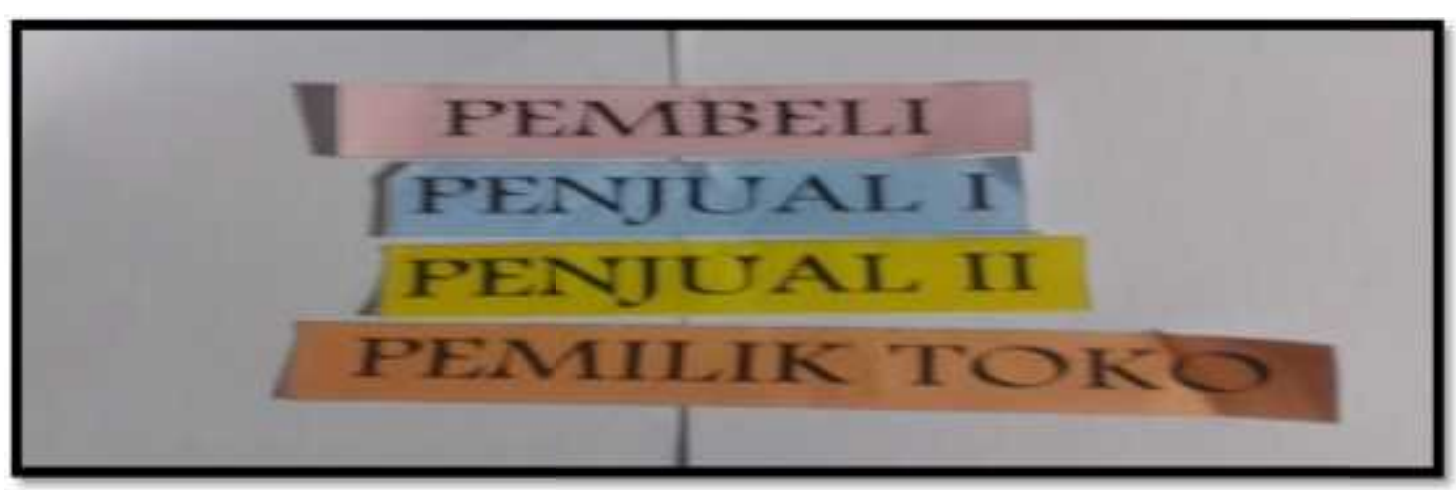

Gambar 4. Label peran

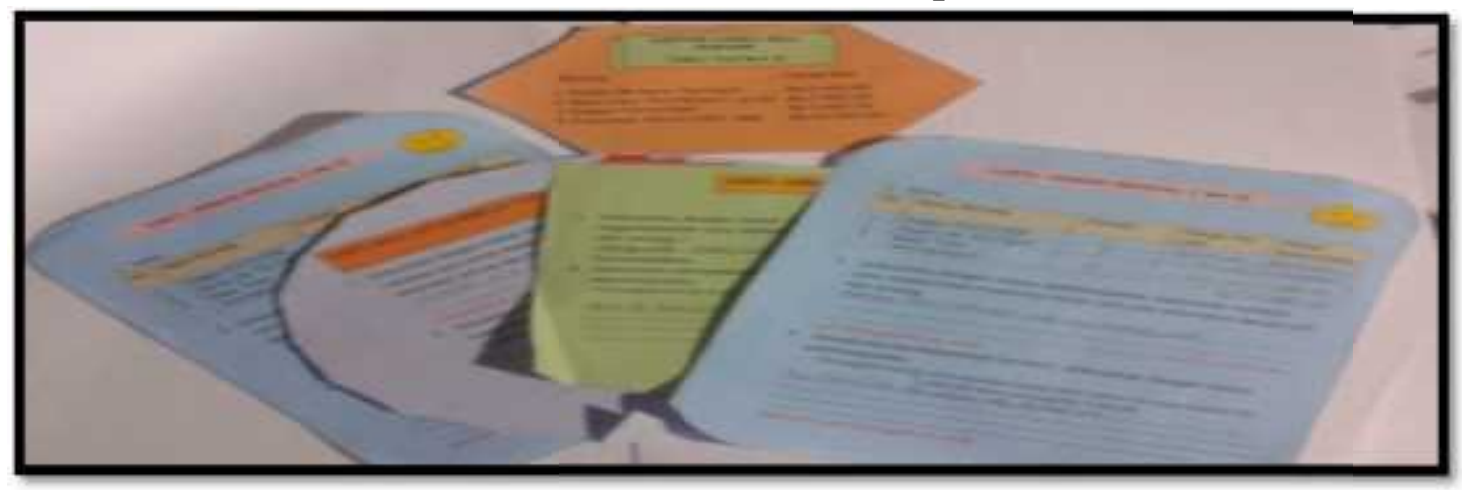

\section{Gambar 5. Kartu adegan siswa}

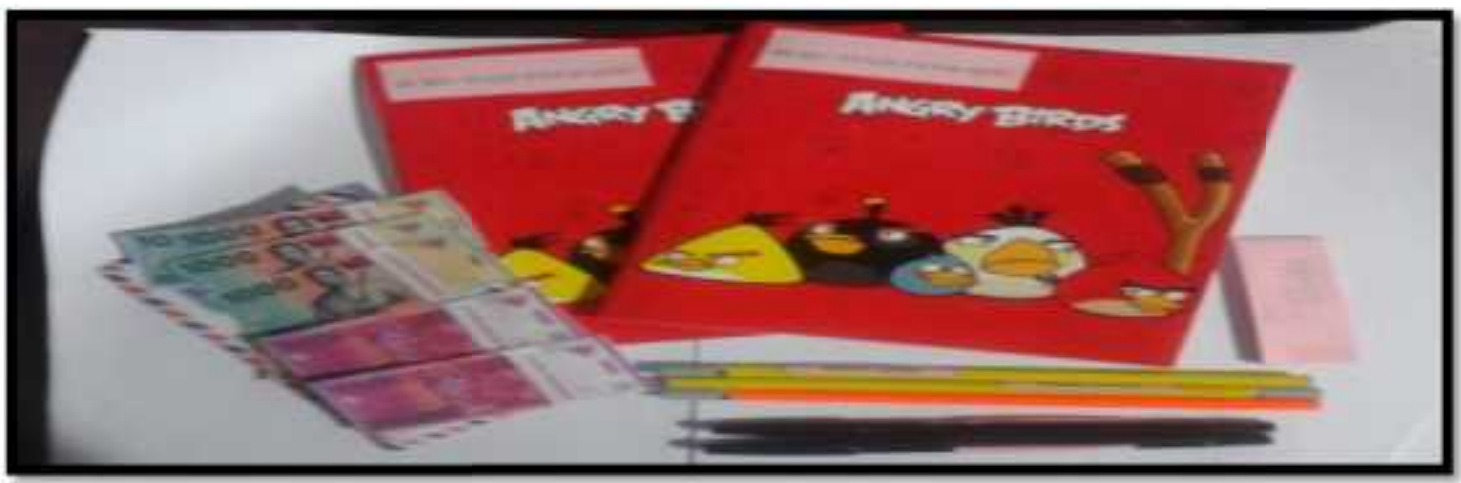

\section{Gambar 6. Properti adegan}

Alternatif yang lain adalah guru dapat memanfaatkan kantin sekolah. Kantin sekolah merupakan sumber belajar yang tepat digunakan untuk berbagai aktivitas pembelajaran bidang matematika khususnya materi aritmatika sosial. Dari sumber belajar kantin banyak digali perihal menghitung nilai keseluruhan, nilai per-unit, menentukan besar dan persentase laba, rugi, harga jual, harga beli, diskon, dan sebagainya. Dari data yang didapat oleh siswa tersebut, diharapkan siswa dapat menghitung persentasi laba/rugi. Dengan adanya sumber belajar tersebut diharapkan dapat membuka wawasan kepada siswa ke depan bila yang bersangkutan ingin menjadi seorang pedagang, minimal sudah mendapatkan informasi awal mengenai apa yang harus dipahami dan dilakukan agar mendapatkan keuntungan, apa yang harus dihindari supaya tidak menderita kerugian, dan sebagainya. Langkah-langkah pelaksanaan pembelajaran menggunakan kantin sekolah sebagai sumber belajar adalah sebagai berikut: 
1) Siswa dibagi dalam kelompok

2) Masing-masing siswa membawa alat tulis dan lembar kerja

3) Sebelum pelaksanaan kegiatan, guru sudah melakukan pendekatan dengan pihak kantin untuk meminta kesediaannya memberikan waktu dan menjawab pertanyaan siswa yang ditugaskan dalam kegiatan kelompok tersebut.

\section{KESIMPULAN}

Kesulitan yang dihadapi siswa dalam mempelajari materi aritmatika sosial adalah:

1. Kesulitan dalam melakukan algoritma penyelesaian soal.

2. Kesulitan dalam memahami konsep untung atau rugi jika dikaitkan dengan harga beli dan harga jual jika dikaitkan dengan harga beli dan harga jual.

3. Kesulitan dalam memahami konsep diskon.

Alternatif pemecahan masalah mengatasi kesulitan yang dihadapi siswa dalam mempelajari materi aritmatika sosial.

1. Alternatif pemecahan untuk mengatasi kesulitan melakukan algoritma penyelesaian soal. Guru perlu membiasakan dan menekankan kepada siswa agar dalam mengerjakan soal selalu disertai dengan langkah-langkah yang jelas. Hal ini sangatlah perlu dibiasakan kepada siswa agar dapat menjawab soal dengan terstruktur sehingga lebih mudah untuk memahami.

2. Alternatif pemecahan untuk mengatasi kesulitan dalam memahami konsep untung atau rugi jika dikaitkan dengan harga beli dan harga jual dan kesulitan dalam memahami konsep diskon. Menerapkan metode Role Playing (bermain peran) dengan memanfaatkan kantin sekolah.

\section{DAFTAR PUSTAKA}

Depdiknas. (2006). Peraturan Pemerintah No.22 Tahun 2006 tentang Standar Kompetensi dan Kompetensi Dasar. Jakarta: Depdiknas.

Achmadi Widdiharto. (2008). Diagnosis Kesulitan Belajar matematika Siswa SMP dan Alternatif Proses Remidinya. Yogyakarta: PPPTK 